Procházka D. (2015). Lobbying on the IASB Standards: An analysis of the Lobbyists' Behaviour over Period 2006-2014. Copernican Journal of Finance \& Accounting, 4(2), 129-143. http:// dx.doi.org/10.12775/CJFA.2015.020

\author{
David ProcházKa* \\ University of Economics, Prague
}

\title{
LOBBYING ON THE IASB STANDARDS: AN ANALYSIS OF THE LOBBYISTS' BEHAVIOUR OVER PERIOD 2006-2014
}

Keywords: Lobbying, Accounting standards, IASB, Rational model of lobbying.

J E L Classification: M41.

\begin{abstract}
The paper investigates whether there is any significant difference in lobbying behaviour on the IASB's projects depending on the type of a project. In particular, we scrutinise the differences in number of comments letters received for: (a) major vs. minor projects; (b) projects successfully completed after the exposure draft phase vs. projects revised/stopped after the exposure draft phase. To test our two hypotheses about the pattern of lobbyist behaviour, we use reasoning based on a rational lobbying model developed by Sutton (1984). Our paper limits the scope to the IASB's projects on its agenda over period 2006-2014; we thus complement previous studies of Kenny \& Larson (1995) and Jorissen et al. (2012), who analysed the lobbying on IASB's standards over periods 1989-1992, and 2002-2006 respectively. Our results show that the IASB inclines to succumb to the pressure of lobbying parties if the lobbying is quite massive (measured by number of comment letters submitted) in relation to other projects. We supplement the literature on lobbying on accounting standards with additional evidence on general ability of the lobbyist to influence the decision of standard-setters by pushing them to revise a project substantially, or even to stop the project in question completely.
\end{abstract}

Date of submission: July 27, 2015; date of acceptance: October 16, 2015.

* Contact information: prochazd@vse.cz, W. Churchill Sq. 4, Prague 130 67, Czech Republic, phone + 420224095125 . 


\section{INTRODUCTION ${ }^{1}$}

Unrestricted number of consumers' needs and limited number of resources available for their satisfaction elicits the conflicts, what economic demands being satisfied via collective action should have priority. Accounting is also affected by these conflicts, which result in existence of various definitions of income and capital and methods for their measurement. The preparers of financial statements have to make choices, which accounting treatment shall be applied to provide users with useful information. Demski (1974) shows on an example of simple economy with actors obtaining information ex-ante and ex-post that information policy alterations, including the changes in accounting choices or changes in accounting standards, are identical to wealth redistributions.

Just a small change in accounting standards may substantially alter the flows of economic benefits to affected parties. These may have strong incentives to influence the process of standard setting. Competing goals create conflicts about the content of accounting standards. An effective solution of conflicts requires establishing of a formalised process for the development of financial reporting standards. The due process (containing public discussions, consultations, invitation of commentary letters, etc.) decreases the risk of conflicts among various groups of users, prepares, auditors, regulators, etc. by inviting them to participate in the preparation phase of new standards. Active participation of interested parties is a necessary condition for legitimacy of the due process and its quality (Durocher, Fortin 2011). The degree of activity also indicates the importance and expected impact of a new standard on benefits of affected parties.

An analysis of lobbying behaviour on standard-setting process is thus an issue of importance for standard-setters (regulators) as well as for accounting research. Next chapter reviews the literature on this topic in more detail. The paper focuses on lobbying on the IASB's International Financial Reporting Standards. The IASB is an independent body and its standard-setting process is not formally subject to any legal or political jurisdiction. The openness of its due process to competing opinions is a must for the general acceptance of proposed guidance. This paper investigates whether there is any signifi-

1 The paper is supported by the Czech Science Foundation under the research project "Economic Impacts of the IFRS Adoption in Selected Transition Countries" (No. 15-01280S); the support is gratefully acknowledged. 
cant difference in lobbying behaviour on the IASB's projects depending on the type of a project. In particular, we scrutinise the differences in number of comments letters received for: (a) major vs. minor projects; (b) projects successfully completed after the exposure draft phase vs. projects revised/stopped after the exposure draft phase. Our paper restricts the scope to the IASB's projects on its agenda over period 2006-2014; we thus complement previous studies of Kenny \& Larson (1995) and Jorissen, Lybaert, Orens, \& Van Der Tas (2012), who analysed the lobbying on IASB's standards over periods 1989-1992, and 2002-2006 respectively. Our results show that the IASB inclines to succumb to the pressure of lobbying parties if the lobbying is quite massive, measured by the number of comment letters submitted to a given project in relation to other projects. We supplement the literature on lobbying on accounting standards with additional evidence on general ability of lobbyist to influence the decision of standard-setters by pushing them to revise a project substantially, or even to stop it completely.

The paper is organised as follows. After this introduction, relevant literature dealing with the lobbying on accounting standards is reviewed. Following the findings from literature overview, two main research hypotheses about the pattern of lobbyists' behaviour are developed. The reasoning is based on a rational lobbying model sketched by Sutton (1984). The hypotheses are empirically tested on the IASB's project agenda over period 2006-2014. The final chapter concludes; the main findings are summarised, the limitations of the study are outlined, and the future stream of research in the area is proposed.

\section{THE RESEARCH METHODOLOGY AND THE COURSE OF THE RESEARCH PROCESS}

The standard setting is often denoted as a political process to depict that the due process is open to wide range of interest groups. They spend scarce resources to change or maintain current status quo and thus to obtain economic benefits (Watts, Zimmerman, 1978; Zeff 2002). The objective of rent seeking (Krueger 1974) in the field of financial reporting is to influence the decision of a standard-setter to set forth such accounting treatments, which may alter the distribution of cash flows or bring other benefits in favour of a lobbying subject (Ordelheide 2004). In this context, the engagement in lobbying transmits signals about the entity to outsiders (Chung 1999). Sutton (1984) outlines the possible motivations for, methods, timing, and other aspects of lobbying. The research on accounting lobbying is usually concentrated (Georgiou 2004) on (a) 
methods (using comment letters, direct contact with standard setters, indirect influence via political representatives, etc.); (b) timing of lobbying (in preparation period, during comment period, etc.); (c) form of participation (on own behalf, as a member of an alliance); (d) arguments used during lobbying (economic, conceptual, etc.).

The accounting literature on lobbying can be divided into two subgroups (Stenka, Taylor 2010). The first stream investigates the motivation of participants of due process, including their attitudes, opinions, objections, and suggestions. Secondly, the ability of lobbyists to influence the decision of standardsetters is under scrutiny. To uncover the reasons, why lobbyists decide to act, is, although, a complicated task, because (a) no robust model of economic rationality of lobbying for all interest groups is available; (b) lobbyists behave strategically; and (c) researchers focus mainly on lobbying through comment letters.

Economic behaviour of an individual lobbyist is shaped by the relation between expected benefits from and costs of lobbying. In case of lobbying on accounting standards (Schalow 1995), cost-benefit analysis requires to assess (a) expected increase in marginal utility of lobbyist from the change in accounting standards; (b) ability to influence the decision of standard-setter; (c) expected costs of lobbying. However, the rational model of lobbying defined by Sutton (1984) may not be sufficient for the analysis of lobbying motivation of aggregate groups or collective bodies. Alternative approaches, e.g. institutional theory (Kenny, Larson 1995; Giner, Arce 2012), are then employed. Regardless the behavioural model used, research is unable to detect the strategic dimension of (non)lobbying (Amershi, Demski, \& Wolfson 1982). Affected parties may surrender lobbying on a relatively less important standard to gain a better position when trying to influence a standard with greater impact on their utility (Zeff 2005). The last limitation of literature on accounting lobbying refers to the fact that researchers cannot rigorously explore other forms of lobbying than those via comment letters (Zülch, Hoffmann 2010). It is impossible to observe all personal meetings of lobbyists with standard-setters and the subject of their talks. Furthermore, lobbyists may act indirectly through politicians. Despite the influence of political pressure on accounting standards is documented quite well (Solomons 1978; Georgiou 2010; Königsgrube, 2010; Zülch, Hoffmann 2010; Zeff 2012; Crawford, Ferguson, Helliar \& Power 2014), the lobbying parties behind politicians are hidden and remain unknown.

Except for the general analysis of lobbying on accounting standards, accounting research also addresses the miscellaneous aspects of lobbying on 
the IASB' activities. Lobbying on particular standards are examined by Kenny \& Larson (1993), Guenther \& Hussein (1995), Larson \& Brown (2001), Chee Chiu Kwok \& Sharp (2005), Giner \& Arce (2012). The lobbying behaviour of preparers is addressed by Larson (1997); the factors influencing the users' decision to (not) lobby are scrutinised by Georgiou (2010); the influence of cultural values on lobbying of accounting bodies is subject of MacArthur (1999)'s study, the national specifics of preparers' lobbying are explored by Orens, Jorissen, Lybaert, \& Van Der Tas (2011). Furthermore, the analysis of formal participation in the IASB's due process through comment letters over the period 1989 and 1992 was processed by Kenny \& Larson (1995). Similar analysis over the period 2002-2006, including the composition and strategy of various lobbying groups, is carried out by Jorissen, Lybaert, Orens, \& Van Der Tas (2012).

Following the literature review, we expect that an interested party will submit a comment letter if expected benefits from the influence of a standard-setter's decision overweight costs to prepare the letter. With reference to the revealed preference theorem (Samuelson 1938), the submission of a comment letter demonstrates that expected benefits are higher than incurred costs, i.e. a lobbyist believes that he/she will be able to modify the attitude of a standardsetter in given case. This rational model of lobbying (Sutton 1984) indicates that the lobbying pressure on major/conceptual/controversial projects shall be higher than lobbying (in the form of a comment letter) on minor amendments of current practice. The costs for preparing a comment letter are relatively constant regardless the type of project; however, possible benefits from influencing the content of a major project are greater than for minor refinements. In this context, we assess whether there is any material distinction in the public commenting on due process documents (i.e. discussion papers, exposure drafts, revised exposure drafts) between major and minor IASB' projects.

H1: The number of comment letters received by the IASB on its major projects is significantly higher than for minor projects. ${ }^{2}$

Secondly, a wide stream of literature - e.g. Kenny \& Larson (1993), Guenther \& Hussein (1995), Larson \& Brown (2001), Chee Chiu Kwok \& Sharp (2005), Giner \& Arce (2012) - documents the successful achievements of lobbyists

2 This classification is used by the IASB and has an important impact on the length and complexity of particular due process (e.g. for minor projects, no discussion papers are issued). 
on particular standards-in-process. We suspect that controversial nature of a proposed standard can be indicated by the number of comments sent by respondents to the Board for their consideration. Once again with reference to the rational model of lobbying (Sutton 1984) and revealed preference theorem (Samuelson 1938), we assume that comment letters address the standard-setter's proposals mainly in negative way trying to achieve a different accounting treatment. An increasing controversy of a project attracts a higher attention and reaction from affected parties, which in turn exposes the IASB to a greater pressure. An increased lobbyists' pressure may weaken the IASB power to defend its position in standard-setting and thus to succumb to lobbyists by significantly revising project or even by stopping it.

H2: The number of comment letters received by the IASB on exposure drafts of the projects, which were revised/stopped, is significantly higher than for the projects successfully completed after the issuance of exposure draft.

\section{THE OUTCOME OF THE RESEARCH PROCESS}

To test both hypotheses, we compiled data on the volume of comments letters received for projects on the IASB's agenda from 2006 (till 2014). Data are available on the IASB website in miscellaneous documents informing about the development of corresponding projects-in-progress and finished projects. The extent of public reaction to the documents issued by the IASB in period 2006 and later is summarised in Tab. 1 - Tab. 4, which present the number of comment letters received to all IASB's projects. ${ }^{3}$ The projects are classified into two groups: major and minor projects. Minor projects (Tab. 4) cover partial amendments to existing standards. As these updates are less complex, only compulsory documents (i.e. exposure drafts) are issued within the due process. Major projects are broken down into three subclasses. The IASB's projects related to financial instruments and projects on Conceptual Framework/Financial Statement Presentation are displayed separately in Tab. 2 and Tab. 3. The numbers of comment letters to remaining major projects are outlined in Tab. 1.

${ }^{3}$ Except for the Annual Improvements, which are left from the analysis aside. 
Table 1. Number of comments letters on IASB's major projects (excluding projects on Financial Instruments, Framework and Presentation)

\begin{tabular}{|c|c|c|c|}
\hline Successfully completed projects & DP & ED & R-ED \\
\hline IFRS 8 & & 178 & \\
\hline IFRS $10 / 12$ & & 156 & \\
\hline IFRS 11 & & 111 & \\
\hline IFRS 13 & 136 & 180 & 91 \\
\hline IFRS 14 & & 100 & \\
\hline IFRS 15 & 211 & 986 & 357 \\
\hline Management commentary & 112 & 103 & \\
\hline IAS 24: Revision & & 72 & 74 \\
\hline Projects in progress & DP & ED & R-ED \\
\hline IFRS 4: Phase II & 158 & 253 & 194 \\
\hline IAS 17: New standard on leases & 290 & 760 & 638 \\
\hline IAS 19: Conceptual revision & 152 & & \\
\hline Paused/stopped projects & DP & ED & R-ED \\
\hline Rate-regulated activities & & 155 & \\
\hline Liabilities & & 212 & \\
\hline Extractive activities & 139 & & \\
\hline Discount rate for Employee benefits & & 106 & \\
\hline
\end{tabular}

S o u r c e : own compilation using the IASB information on projects available at http://www.ifrs. org/Current-Projects/IASB-Projects/Pages/All_projects.aspx.

N o t e : DP (Discussion Paper); ED (Exposure Draft); R-ED (Revised Exposure Draft)

Table 2. Number of comments letters on Financial Instruments related projects

\begin{tabular}{|l|c|c|c|}
\hline \hline \multicolumn{1}{|c|}{ Projects on financial instruments } & DP & ED & R-ED \\
\hline \hline Financial instruments: joint DP for Phase I-III & & & \\
\hline Reducing complexity in Reporting Financial Instruments & 162 & & \\
\hline Phase I: Classification and measurement & & & \\
\hline Financial instruments: classification and measurement & & 210 & \\
\hline Fair value option for financial liabilities & & 125 & \\
\hline
\end{tabular}




\begin{tabular}{|c|c|c|c|}
\hline Projects on financial instruments & DP & ED & R-ED \\
\hline $\begin{array}{l}\text { Classification and measurement: limited amendments } \\
\text { to IFRS } 9\end{array}$ & & 167 & \\
\hline \multicolumn{4}{|l|}{ Phase II: Impairment } \\
\hline Request for information & 79 & & \\
\hline Financial instruments: impairment & & 187 & \\
\hline $\begin{array}{l}\text { Financial instruments: impairment (supplementary docu- } \\
\text { ments) }\end{array}$ & & 180 & \\
\hline \multicolumn{4}{|l|}{ Phase III: Hedge accounting } \\
\hline Hedge accounting & & 216 & \\
\hline \multicolumn{4}{|l|}{ Other minor projects on Financial instruments } \\
\hline Exposures qualifying for hedge accounting & & 75 & \\
\hline Financial Instruments: puttable instruments & & 88 & \\
\hline Asset and liability offsetting & & 162 & \\
\hline
\end{tabular}

S o u r c e : own compilation using the IASB information on projects available at http://www.ifrs. org/Current-Projects/IASB-Projects/Pages/All_projects.aspx.

Table 3. Number of comments letters on other IASB's major projects

\begin{tabular}{|l|c|c|c|}
\hline \multicolumn{1}{|c|}{ Conceptual Framework projects } & DP & ED & R-ED \\
\hline \hline CR Phase A (Jul 2006) & & 179 & \\
\hline CR Phase B (Nov 2005) & 86 & & \\
\hline CR Phase D (Mar 2010) & & 114 & \\
\hline CR Review (Jul 2013) & 243 & & R-ED \\
\hline \hline \multicolumn{1}{|c|}{ Financial Statements Presentation projects } & DP & ED & \\
\hline \hline IAS 1 Phase A (Mar 2006) & & 126 & \\
\hline IAS 1 Phase B-I (Oct 2008) & 229 & & \\
\hline IAS 1 Phase B-II (May 2010) & & 150 & \\
\hline \hline
\end{tabular}

S o u r c e : own compilation using the IASB information on projects available at http://www.ifrs. org/Current-Projects/IASB-Projects/Pages/All_projects.aspx. 
Table 4. Number of comments letters on IASB's minor amendments to existing projects

\begin{tabular}{|l|l|l|c|}
\hline \multicolumn{1}{|c|}{ Amendment } & ED & \multicolumn{1}{|c|}{ Amendment } & ED \\
\hline \hline IAS 16/IAS 38 (Dec 2012) & 98 & IFRS 10/IAS 28 (Dec 2012) & 65 \\
\hline IAS 16/IAS 41 (Jun 2013) & 16 & IFRS 10/IFRS 12/IAS 28 (Aug 2011) & 170 \\
\hline IAS 23 (May 2006) & 89 & IFRS 11 (Dec 2012) & 70 \\
\hline IAS 27 (Dec 2013) & 60 & IFRS 2 (Dec 2007) & 44 \\
\hline IAS 27 (Jun 2005) & 94 & IFRS 2 (Feb 2006) & 78 \\
\hline IAS 33 (Aug 2008) & 57 & IFRS 3 (June 2005) & 61 \\
\hline IAS 36 (Jan 2013) & 76 & IFRS 5 (Sep 2008) & 93 \\
\hline IAS 39 (Dec 2008) & 54 & IFRS 7 (Dec 2008) & 121 \\
\hline IFRS 1 (Oct 2011) & 39 & IFRS 7 (Mar 2009) & 88 \\
\hline IFRS 10 (Dec 2011) & 14 & IFRS 7 (Oct 2011) & 72 \\
\hline \hline
\end{tabular}

S o u r c e : own compilation using the IASB information on projects available at http://www.ifrs. org/Current-Projects/IASB-Projects/Pages/All_projects.aspx.

Projects on revenue recognition and accounting for leases are the most controversial, taking into account the number of comment letters received. The Project on Leases is on the top, as far as a total number of responses submitted during the whole due process concerns (almost 1,700 in total for all three documents). Similarly, the Revenue Recognition Project evidences the highest number of comment letters received for a single due process document (almost 1,000 letters reacting on the Exposure Draft). The descriptive statistics on all comment letters are summarised in Tab. 5.

Table 5. Number of comments letters: descriptive statistics

\begin{tabular}{|l|c|c|c|c|c|c|c|c|c|}
\hline \hline & \multicolumn{4}{|c|}{ Major projects } & \multicolumn{3}{c|}{ Minor projects } & \multicolumn{3}{c|}{ Total } \\
\cline { 2 - 11 } & DP & ED & R-ED & DP & ED & R-ED & DP & ED & R-ED \\
\hline \hline Mean & 166.4 & 205.8 & 270.8 & $\mathrm{x}$ & 72.0 & $\mathrm{x}$ & 166.4 & 147.6 & 270.8 \\
\hline Median & 155.0 & 159.0 & 194.0 & $\mathrm{x}$ & 67.5 & $\mathrm{x}$ & 155.0 & 104.5 & 194.0 \\
\hline St. deviation & 62.0 & 200.4 & 209.4 & $\mathrm{x}$ & 34.4 & $\mathrm{x}$ & 62.0 & 166.2 & 209.4 \\
\hline
\end{tabular}




\begin{tabular}{|l|c|c|c|c|c|c|c|c|c|}
\hline \hline & \multicolumn{4}{|c|}{ Major projects } & \multicolumn{3}{c|}{ Minor projects } & \multicolumn{3}{c|}{ Total } \\
\cline { 2 - 10 } & DP & ED & R-ED & DP & ED & R-ED & DP & ED & R-ED \\
\hline \hline Min & 79.0 & 72.0 & 74.0 & $\mathrm{x}$ & 14.0 & $\mathrm{x}$ & 79.0 & 14.0 & 74.0 \\
\hline $\operatorname{Max}$ & 290.0 & 986.0 & 638.0 & $\mathrm{x}$ & 170.0 & $\mathrm{x}$ & 290.0 & 986.0 & 638.0 \\
\hline \hline
\end{tabular}

S o u r c e : own calculation.

Total descriptive statistics for all projects are also partitioned into two subgroups: major projects (based on data from Tab. 1 - Tab. 3) and minor amendments to existing projects (based on data from Tab. 4). The separation controls for the different structure and importance of major and minor projects. The due process of minor amendments contains only compulsory elements, i.e. exposure drafts. Discussion papers are published for some major projects only; exposure drafts of major projects are sometimes revised, if the first exposure draft is strongly objected.

As minor projects contain only exposure drafts, we are able to compare the magnitude of public reaction just in case of this due process document. As assumed by $\mathrm{H} 1$, the average number of comment letters is substantially higher for major projects (3 times higher than for minor amendments). We test whether this difference is statistically significant, using the analysis of variance (Tab. 6). The test's results provide support for our prediction that respondents consider material differences in importance between major and minor projects.

Table 6. Analysis of variance:

number of comment letters according to the type of project

\begin{tabular}{|l|c|c|c|c|c|}
\hline \hline \multicolumn{1}{|c|}{ ANOVA } & SS & dF & MS & F & p-value \\
\hline \hline Treatment & 202550 & 1 & 202550 & 8.348 & 0.006 \\
\hline Residual & 1067535 & 44 & 24262 & & \\
\hline Total & 1270085 & 45 & & & \\
\hline \hline
\end{tabular}

S o u r c e : own calculation.

An intuitive presumption, based on the literature review and supported by the descriptive statistics, that major projects attract more attention from interested parties, is confirmed by p-value of the F-test. Active participation of lobbyists in major projects is significantly higher than in case of minor amendments. We may conclude that major projects (including both the most lobbied 
projects on revenue recognition and accounting for leases) have a dominant position not only in the IASB' agenda, but also from the view point of commenting parties.

Secondly, we test $\mathrm{H} 2$, i.e. whether a high rate of comment letters submitted by lobbying parties is more likely followed by the failure of exposure draft to supply an acceptable accounting treatment for a given area of financial reporting. The IASB's failure to deliver an exposure draft, being broadly accepted by public, may be resolved either by (a) publishing a revised exposure draft; or by (b) stopping the project. Once again, we use the analysis of variance to verify, whether a number of comments on an exposure draft matters in the IASB's deliberations on further development of the corresponding project. The results are presented in Tab. 7.

Table 7. The magnitude of lobbying and its influence on results of project development

\begin{tabular}{|l|c|c|c|c|c|}
\hline \hline \multicolumn{1}{|c|}{ ANOVA } & SS & dF & MS & F & p-value \\
\hline \hline Treatment & 360321 & 1 & 360321 & 17.427 & 0.000 \\
\hline Residual & 909764 & 44 & 20676 & & \\
\hline Total & 1270085 & 45 & & & \\
\hline \hline
\end{tabular}

S o u r c e : own calculation.

The analysis of variance reveals that magnitude of lobbying is significantly associated with the IASB's decision on the further direction of project development. More specifically, with the increasing number ${ }^{4}$ of comment letters on an exposure draft, the project will be more likely revised or even stopped. The results show that the IASB inclines to succumb to the pressure of lobbying parties if the lobbying is quite massive (in terms of number comment letters submitted) in relation to other projects.

${ }^{4}$ Using the same data from Tab. 1 - Tab. 4, the mean of comment letters on exposure drafts of projects revised or stopped is 340, compared to an average of 107 comments received on projects, during which an exposure draft was successfully transposed into an effective standard. 


\section{CONCLUSIONS}

The paper replenishes previous studies analysing the lobbying on IASB's standards. Our analysis covers the period 2006-2014 and confirms predictions based on the rational model of lobbying. The lobbying behaviour through comment letters depends on the importance of project, which determines potential benefits from incurring lobbying costs. Major projects (as labelled by the IASB) attract a broader attention from interested parties, which is expressed (usually) by negative attitude in their comments. Furthermore, an increasing rate of public discordant comments boosts the opportunity of lobbyists to influence the decision-making of IASB; especially by pressing the standard-setters to revise or stop the accounting treatments suggested in respective exposure draft.

By analysis of the volume of comment letters received by the IASB as a reaction of public to its recent projects-in-progress, we complement previous studies for period before 2006 and contribute to the current state of art in the field in following ways. Firstly, we document that major projects are subject of a significantly higher extend of comments by lobbying parties. Furthermore, the participation of constituents is steadily rising through the development of a project. Lowest participation is present for the discussion papers (which outline "only" tentative solutions and conceptual questions); exposure drafts proposing binding accounting treatments attract a higher attention. Secondly, our analysis demonstrates that projects, which were revised or stopped by the IASB, are associated with a significantly higher volume of dissenting comment letters than projects successfully finished after the issuance of an exposure draft. These findings indicate that commenting bodies are repeatedly able to influence the decisions taken by the IASB. As the paper deals with aggregate data for all recent projects over period 2006-2014, we provide additional evidence on this issue to previous studies analysis lobbying on single standards.

However, our paper has also some limitations resulting from the methodology applied. Firstly, using aggregate data on number of comment letters, we are unable to detect what were the main reasons of a strong disagreement by public for each project and what drove the IASB's decisions to revise or stop the project subsequently. Furthermore, we did not analyse the composition of respondents, which may have revealed some additional evidence on lobbying behaviour and differences in relative importance of particular groups of lobbyists and their influence on the IASB's decisions. These two shortcomings can be overcome by a detailed analysis of all comment letters. However, as the to- 
tal comment letter for all projects presented in Tab. 1 - Tab. 4 are over 10,000, a deep analysis is possible only for single projects, as done previously e.g. by Kenny \& Larson (1993), Guenther \& Hussein (1995), Larson \& Brown (2001), Chee Chiu Kwok \& Sharp (2005), Giner \& Arce (2012), but not on aggregate level. This is our main suggestion for future research in the field.

Secondly, a sole focus on comment letters disregards other ways, which can be used by affected parties to lobby on the IASB's proposals. However, an indirect influence via political representatives is hardly observable, as the lobbying parties behind politicians are hidden. Similarly, acting through a direct contact with standard setters is also discernible with difficulties, as it is unfeasible to observe all personal meetings of lobbyists with standard-setters and to record the subject of their talks. Researchers may trace e.g. the IASB's outreach activities, during which a project is introduced to and discussed with public. However, a full personal participation at all meetings is not achievable; e.g. between May 2013 and November 2013, the IASB met with constituents in 186 individual and group meetings in 18 countries to discuss the project on insurance contracts. This limitation is, although, common to all studies on lobbying on accounting standards (Zülch, Hoffmann 2010).

\section{REFERENCES}

Amershi, A. H., Demski, J. S., \& Wolfson, M. A. (1982). Strategic Behavior and Regulation Research in Accounting. Journal of Accounting and Public Policy, 1(1), 19-32. http:// dx.doi.org/10.1016/0278-4254(82)90004-7.

Chee Chiu Kwok, W., \& Sharp, D. (2005). Power and International Accounting Standard Setting: Evidence from Segment Reporting and Intangible Assets Projects. Accounting, Auditing \& Accountability Journal, 18(1), 74-99. http://doi.org/10.1108/095135 70510584665 .

Chung, D. Y. (1999). The Informational Effect of Corporate Lobbying Against Proposed Accounting Standards. Review of Quantitative Finance \& Accounting, 12(3), 243-269.

Crawford, L., Ferguson, J., Helliar, C. V., \& Power, D. M. (2014). Control over Accounting Standards within the European Union: The Political Controversy Surrounding the Adoption of IFRS 8. Critical Perspectives on Accounting, 25(4-5), 304-318. http:// dx.doi.org/10.1016/j.cpa.2013.03.001.

Demski, J. S. (1974). Choice among Financial Reporting Alternatives. The Accounting Review, 49(2), 221-232.

Durocher, S., \& Fortin, A. (2011). Practitioners' Participation in the Accounting Standard-Setting Process. Accounting and Business Research, 41(1), 29-50.

Georgiou, G. (2004). Corporate Lobbying on Accounting Standards: Methods, Timing and Perceived Effectiveness. Abacus, 40(2), 219-237. 
Georgiou, G. (2010). The IASB Standard-setting Process: Participation and Perceptions of Financial Statement Users. The British Accounting Review, 42(2), 103-118. http://doi.org/10.1016/j.bar.2010.02.003.

Giner, B., \& Arce, M. (2012). Lobbying on Accounting Standards: Evidence from IFRS 2 on Share-Based Payments. European Accounting Review, 21(4), 655-691. http:// doi.org/10.1080/09638180.2012.701796.

Guenther, D. A., \& Hussein, M. E. A. (1995). Accounting Standards and National Tax Laws: The IASC and the Ban on LIFO. Journal of Accounting and Public Policy, 14(2), 115-141. http://doi.org/10.1016/0278-4254(95)00001-U.

Jorissen, A., Lybaert, N., Orens, R., \& Van Der Tas, L. (2012). Formal Participation in the IASB's Due Process of Standard Setting: A Multi-issue/Multi-period Analysis. European Accounting Review, 21(4), 693-729. http://doi.org/10.1080/09638180.2010. 522775 .

Kenny, S. Y., \& Larson, R. K. (1993). Lobbying Behaviour and the Development of International Accounting Standards: The Case of the IASC's Joint Venture Project. European Accounting Review, 2(3), 531-554. http://doi.org/10.1080/09638189300000050.

Kenny, S. Y., \& Larson, R. K. (1995). The Development of International Accounting Standards: An Analysis of Constituent Participation in Standard-Setting. International Journal of Accounting, 30(4), 283-301.

Königsgruber, R. (2010). A Political Economy of Accounting Standard Setting. Journal of Management \& Governance, 14(4), 277-295. http://doi.org/10.1007/s10997-0099101-1.

Krueger, A. O. (1974). The Political Economy of the Rent-Seeking Society. The American Economic Review, 64(3), 291-303.

Larson, R. K. (1997). Corporate Lobbying of the International Accounting Standards Committee. Journal of International Financial Management and Accounting, 8(3), 175-203. http://doi.org/10.1111/1467-646X.00024.

Larson, R. K., \& Brown, K. L. (2001). Lobbying of the International Accounting Standards Committee: The Case of Construction Contracts. Advances in International Accounting, 14, 47-73. http://doi.org/10.1016/S0897-3660(01)14005-5.

MacArthur, J. B. (1999). The Impact of Cultural Factors on the Lobbying of the International Accounting Standards. Journal of International Accounting, Auditing \& Taxation, 8(2), 315. http://doi.org/10.1016/S1061-9518(99)00018-X.

Ordelheide, D. (2004). The Politics of Accounting: A Framework. In The Economics and Politics of Accounting: International Perspectives on Research Trends, Policy, and Practice (p. 404). New York: Oxford University Press.

Orens, R., Jorissen, A., Lybaert, N., \& Van Der Tas, L. (2011). Corporate Lobbying in Private Accounting Standard Setting: Does the IASB have to Reckon with National Differences? Accounting in Europe, 8(2), 211-234. http://doi.org/10.1080/17449480. 2011.621672.

Samuelson, P. A. (1938). A Note on the Pure Theory of Consumer's Behaviour. Economica, 5(17), 61-71. http://doi.org/10.2307/2548836.

Schalow, C. M. (1995). Participation Choice: The Exposure Draft for Postretirement Benefits Other Than Pensions. Accounting Horizons, 9(1), 27-41. 
Solomons, D. (1978). The Politicization of Accounting. Journal of Accountancy, 146(5), 65-72.

Stenka, R., \& Taylor, P. (2010). Setting UK Standards on the Concept of Control: An Analysis of Lobbying Behaviour. Accounting and Business Research, 40(2), 109-130. http://doi.org/10.1080/00014788.2010.9663387.

Sutton, T. G. (1984). Lobbying of Accounting Standard-Setting Bodies in the U.K. and the U.S.A.: A Downsian Analysis. Accounting, Organizations and Society, 9(1), 81-95. http://doi.org/10.1016/0361-3682(84)90031-X.

Watts, R. L., \& Zimmerman, J. L. (1978). Towards a Positive Theory of the Determination of Accounting Standards. The Accounting Review, 53(1), 112-134.

Zeff, S. A. (2002). "Political" Lobbying on Proposed Standards: A Challenge to the IASB. Accounting Horizons, 16(1), 43-54. http://dx.doi.org/10.2308/acch.2002.16.1.43.

Zeff, S. A. (2005). The Evolution of U.S. GAAP: The Political Forces Behind Professional Standards. CPA Journal, 75(2), 19-29.

Zeff, S. A. (2012). The Evolution of the IASC into the IASB, and the Challenges it Faces. The Accounting Review, 87(3), 807-837. http://dx.doi.org/10.2308/accr-10246.

Zülch, H., \& Hoffmann, S. (2010). Lobbying on Accounting Standard Setting in a Parliamentary Environment-A Qualitative Approach. HHL Working Paper. 94, 53. 
